УДК 343.98

DOI https://doi.org/10.51989/NUL.2021.6.33

\title{
КРИМІНАЛІСТИЧНА КЛАСИФІКАЦІЯ ЗЛОЧИНІВ ПРОТИ СТАТЕВОЇ СВОБОДИ ТА СТАТЕВОЇ НЕДОТОРКАНОСТІ ДІТЕЙ
}

\author{
Нікітіна-Дудікова Ганна Юріївна, \\ ORCID: 0000-0002-8865-0061 \\ кандидат юридичних наук, \\ доцент кафедри криміналістики та судової медицини \\ Національної академії внутрішніх справ
}

У статті досліджено питання про визначення класифікаційних підстав до створення криміналістичної класифікації злочинів проти статевої свободи і статевої недоторканості дітей.

Установлено, що криміналістична класифікація злочинів спрямована на вдосконалення i розвиток методик розслідування окремих категорій злочинів, сприяючи деталізації, з'ясуванню особливостей їхніх криміналістичних характеристик.

Визначено, що питання про критерії класифікації $\epsilon$ найважливішим під час побудови класифікації злочинів, оскільки воно є детермінантом теоретичного і практичного значення класифікації загалом.

Окреслено різні класифікації злочинів проти статевої свободи і статевої недоторканості дітей, зупинившись окремо на найбільш значущих із них стосовно практики їхнього розслідування.

Визначено суто криміналістичні ознаки як класифікаційну основу криміналістичної класифікації злочинів проти статевої свободи і статевої недоторканості дітей: 1) особа злочинця; 2) особа потерпілого; 3) спосіб учинення злочину; 4) слідова картина; 5) обстановка вчинення злочину.

Класифіковано особу злочинця за соціально-демографічними ознаками (статтю, віком, освітою, зайнятістю, наявністю попередньої судимості), за психологічними властивостями і моральними якостями, сексуальною орієнтацією, кількісним складом, характером вчинюваних дій.

Особу потерпілого класифіковано за відомостями анкетного характеру (стать, вік, сімейний стан), віктимністю та рисами характеру, особливостями поведінки (до злочинної події, У момент учинення злочину, після його вчинення).

Класифіковано спосіб учинення злочину: за стадією або за структурою способу вчинення злочину; за наявністю спротиву вчинюваним діям; за способом подолання опору дитини; за характером дій, спрямованих на досягнення злочинного результату.

Слідову картину класифіковано за слідосприймаючим об'єктом; за наявністю геномної інформації людини; за процесуальним статусом особи, яка зберегла у своїй пам'яті ідеальні сліди.

Обстановку вчинення злочину класифіковано за локалізацією злочинних дій, за ознаками місць безпосереднього вчинення злочинів, за часом доби.

Ключові слова: злочини проти статевої свободи та статевої недоторканості дітей; криміналістична класифікація.

\section{Nikitina-Dudikova Ganna. Criminalistic classification of crimes against sexual freedom and sexual inviolity of children}

The article examines the issue of determining the classification grounds for the creation of a criminal classification of crimes against sexual freedom and sexual integrity of children.

Found that criminological classification of crimes aimed at improvement and the development of methods for investigating certain categories of crimes, providing details, the emergence of the features of their criminal characteristics..

It is determined that the question of the classification classification is the most important in constructing the classification of crimes, as it is a determinant of the theoretical and practical significance of the classification.

Different classifications of crimes against sexual freedom and sexual integrity of children are outlined, focusing on the most significant from the standpoint of the practice of their investigation. 
Purely forensic features are defined as the classification basis of the forensic classification of crimes against sexual freedom and sexual integrity of children: 1) the identity of the offender; 2) the identity of the victim; 3) the manner of committing the crime; 4) trace picture; 5) the circumstances of the crime.

The identity of the offender is classified according to socio-demographic characteristics (gender, age, education, employment, previous criminal record); psychological properties and moral qualities; sexual orientation; by quantitative composition; by the nature of the actions.

The identity of the victim is classified according to: information of a personal nature (sex, age, marital status); victimhood and character traits; peculiarities of behavior - before the criminal event, at the time of the crime, after its commission.

The method of committing a crime is classified: by stage or structure of the method of committing a crime; in the presence of resistance to the committed actions; by way of overcoming the child's resistance; by the nature of actions aimed at achieving a criminal result.

The trace pattern is classified according to the trace object; in the presence of human genomic information; according to the procedural status of the person who has preserved in his memory the ideal traces.

The situation of the crime is classified by the location of criminal acts; on the grounds of places of direct commission of crimes; by time of day.

Key words: crimes against sexual freedom and sexual integrity of children; forensic classification.

Постановка проблеми. Криміналістика як прикладна наука покликана забезпечувати практичних співробітників потрібним інструментарієм, методами і засобами, алгоритмом дій під час розслідування тих чи інших видів злочинів. Із цією метою наукою вдосконалюються старі та створюються нові криміналістичні методики.

Формування методики розслідування злочинів проти статевої свободи і статевої недоторканості дітей потребує визначення концептуального підходу до встановлення механізму їх створення, одним із інструментів якого $€$ криміналістична класифікація злочинів.

Нині потрібно констатувати, що методика розслідування злочинів проти статевої свободи та статевої недоторканості дітей у вітчизняних наукових працях комплексно не розглядалася, як і не проводилася криміналістична класифікація зазначеного виду злочину за криміналістично значущими підставами.

Тому ми вважаємо за потрібне запропонувати криміналістичну класифікацію злочинів проти статевої свободи та статевої недоторканості дітей.

Аналіз останніх досліджень і публікацій. Проблеми розслідування насильницьких статевих злочинів щодо дітей були предметом наукових досліджень у працях М. В. Корнієнка [1], С.М. Авраменко [2], О.В. Гірук [3].
Криміналістичну класифікацію у своїх роботах досліджували також В.В. Тіщенко [4], В.Л. Синчук [5], Т.А. Пазинич [6], I.I. Попович [7], P.С. Довбаш [8] та інші.

Метою роботи $\epsilon$ дослідження криміналістичної класифікації злочинів проти статевої свободи та статевої недоторканості дітей.

Виклад основного матеріалу дослідження.

Криміналістична класифікація злочинів спрямована на вдосконалення і розвиток методик розслідування окремих категорій злочинів, сприяючи деталізації, з'ясуванню особливостей їхньої криміналістичної характеристики [4, с. 41]. Криміналістичні класифікації злочинів дозволяють оптимізувати процес криміналістичної діяльності, оскільки сприяють розробленню гнучких і ситуативно пристосованих криміналістичних методик [9, с. 248].

Розробляючи криміналістичну класифікацію злочинів, слід звертатися до методу типізації, який містить виділення істотного у досягнутому знанні. Визначення того, що $\epsilon$ істотним, розрізнення більш істотного від менш істотного - одне із найскладніших пізнавальних завдань [10, с. 30]. Тому основним питанням $є$ визначення того, що потрібно покласти в основу криміналістичної класифікації злочинів загалом і злочинів проти статевої свободи та статевої недоторканості дітей зокрема. 
Питання про критерії (підстави) класифікації $\epsilon$ найважливішим під час побудови класифікації злочинів, оскільки воно $\epsilon$ детермінантом теоретичного і практичного значення класифікації загалом і спрямовано на вирішення тих цілей та задач, які перед нею постають [11, с. 143].

На практиці кожний злочин визначається за декількома класифікаціями, що відображається у змісті конкретних окремих криміналістичних методик. Водночас до уваги беруться лише ті криміналістично значущі ознаки, які істотно впливають на основні складники вчинення злочину, тобто саме вони обумовлюють особливості вчинення злочину і можливості використання відомостей про це для оптимізації процесу розслідування [12, с. 20].

У контексті пізнання криміналістично значущого об'єкта доцільним $€$ побудова всіх можливих його класифікацій із метою отримання певних систем наукового знання і подальшого вибору із цих систем найоптимальніших для вирішення поставленої проблеми.

Тому під час дослідження ми окреслимо різні класифікації злочинів проти статевої свободи і статевої недоторканості дітей, зупинившись окремо на найбільш значущих із позиції практики їхнього розслідування.

Криміналістичне значення такого поділу полягає у можливості групування злочинів за схожими способами вчинення, а відтак і близькою слідовою картиною, ознаками, притаманними особі потерпілої дитини чи особі злочинця, що є суттєвим для формування відповідних криміналістичних характеристик.

Під час побудови криміналістичної класифікації злочинів проти статевої свободи і статевої недоторканості дітей нами застосовуватимуться суто криміналістичні ознаки як класифікаційна основа, якими $\epsilon:$ 1) особа злочинця; 2) особа потерпілого; 3) спосіб учинення злочину; 4) слідова картина; 5) обстановка вчинення злочину.

Криміналістична класифікація особи злочинця

Особу злочинця можна класифікувати за його криміналістично значущими ознаками, якими у контексті розслідування злочинів проти статевої свободи і статевої недоторканості дітей $\epsilon:$ 1) соціально-демографічні ознаки; 2) психологічні властивості та моральні якості; 3) біологічні ознаки. У групі соціально-демографічних ознак нами виділено відомості про стать, вік, освіту, зайнятість і наявність попередньої судимості.

Отже, за зазначеними критеріями особу злочинця, який учинив злочин проти статевої свободи і статевої недоторканості дитини, можна класифікувати таким чином:

- за статтю (гендерним критерієм): злочини, вчинені особою чоловічої статі; злочини, вчинені особою жіночої статі; злочини, які вчиняються за одночасною участю особами чоловічої і жіночої статі;

- за віком: злочини, вчинені особою у віці до 14 років; злочини, вчинені особою у віці 14-15 років; злочини, вчинені особою у віці 16-17 років; злочини, вчинені особою у віці 18-28 років; злочини, вчинені особою у віці 29-29 років; злочини, вчинені особою у віці 40-54 роки; злочини, вчинені особою у віці 55-59 років; злочини, вчинені особою у віці старше 60 років;

- за освітою: злочини, вчинені особою без освіти; злочини, вчинені особою із початковою середньою освітою; злочини, вчинені особою з базовою середньою освітою; злочини, вчинені особою із професійно-технічною освітою; злочини, вчинені особою з вищою освітою;

- за зайнятістю: злочини, вчинені особою, яка навчається; злочини, вчинені особою працездатного віку, але не працюючою; злочини, вчинені особою працюючою; злочини, вчинені безробітною особою; злочини, вчинені непрацездатною особою;

- за наявністю попередньої судимості: злочини, вчинені особою вперше; злочини, вчинені особою, яка раніше притягувалася до кримінальної відповідальності за аналогічні злочини; злочини, вчинені особою, яка раніше притягувалася до кримінальної відповідальності за вчинення злочинів іншого характеру;

- за наявністю психічного відхилення, під впливом якого застосовувалося сексуальне насильство щодо дитини: особи із чітко вираженим психічним захворю- 
ванням; особи із порушеннями психосексуального розвитку за нормального загального психічного розвитку; особи, які вчинили сексуальне насильство щодо дитини, перебуваючи у стані алкогольного чи наркотичного сп'яніння, зокрема алкоголіки; психічно здорові особи;

- за сексуальною орієнтацією: гетеросексуали; гомосексуалісти; бісексуали;

- за кількісним складом: злочини, вчинені одноособово; злочини, вчинені групою осіб.

На нашу думку, найінформативнішою з позиції практики розслідування злочинів проти статевої свободи і статевої недоторканості дітей за критерієм особи злочинця $\epsilon$ класифікація за характером вчинюваних дій: інфантильний тип, девіантний тип, регресивний тип, садист. Зазначена класифікація впливає на спосіб учинення дій та, відповідно, на слідову картину вчинюваного злочину.

Криміналістична класифікація особи потерпілого

Особу потерпілого можна класифікувати аналогічно класифікації особи злочинця, тобто за криміналістично значущими ознаками, такими як соціально-демографічні ознаки (стать, вік, сімейний стан), віктимність та риси характеру, особливості поведінки (до злочинної події, у момент вчинення злочину, після його вчинення).

Класифікація за статтю: злочини, вчинені щодо дитини жіночої статі; злочини, вчинені щодо дитини чоловічої статі.

На нашу думку, криміналістично значущою $є$ класифікація особи потерпілого за віком, оскільки вік потерпілої дитини впливає на вид вчинюваного щодо неї злочину проти статевої свободи і статевої недоторканості: чим старшою $є$ дитина за віком, тим більше злочин характеризується наявністю фізичного контакту і проникненням у тіло потерпілої особи. I, навпаки, чим дитина молодша, тим частіше злочин учиняється без наявності фізичного контакту між потерпілою особою та без проникнення в тіло потерпілої особи, а спрямований у більшості випадків на інтелектуальне розбещення дитини.

Період неповноліття із погляду на психоемоційне дозрівання особи розглядається як великий період, що поділяється на певні вікові етапи, кожен із яких $\epsilon$ від- різком життєвого шляху і певним щаблем ії розвитку як особистості з характерними для неї відносно стійкими якісними особливостями.

М.В. Савчином та Л. П. Василенко запропоновано класифікацію дітей за віком на такі групи: 1) вік немовляти (до 1 року); 2) раннє дитинство (від 1 до 3 років); 3) дошкільний вік (від 3 до 6-7 років); 4) молодший шкільний вік (від 6-7 до 11-12 років); 5) підлітковий вік (від 11-12 до 14-15 років); 6) вік ранньої юності (від 14-15 до 18 років) $)^{1}$.

Узявши за основу напрацювання науковців, ми розглядатимемо особу потерпілої дитини від злочинів проти статевої свободи та статевої недоторканості щодо такої класифікації за віком: потерпіла особа у віці до 1 року; потерпіла особа у віці від 1 до 3 років; потерпіла особа у віці від 3 до 6 років; потерпіла особа у віці від 6 до 10 років; потерпіла особа від 11 до 14 років; потерпіла особа у віці від 14 до 16 років; потерпіла особа у віці від 16 до 18 років.

За сімейним станом і взаємовідносинами у сім'ї особу потерпілого можна класифікувати як дитину із благополучної сім'ї, дитину зі змістовно неблагополучної сім'ї, дитину зі структурно неблагополучної сім'ї.

Класифікація за критерієм віктимності: потерпілі, не здатні адекватно оцінити віктимну ситуацію; потерпілі, здатні оцінити небезпеку, але не передбачили кримінальних наслідків (характерно для злочинів, учинених батьками, вітчимом, педагогами та іншими); потерпілі, здатні оцінити віктимність ситуації, яка передувала злочину, але нехтують заходами особистої безпеки; потерпілі, які сприяли своєю поведінкою вчиненню злочину.

На підставі попередньої класифікації можна запропонувати класифікацію за характером вини: абсолютно невинні (ідеальні жертви); жертви із легкою провиною (жертва як результат незнання); жертви, вина яких рівнозначна вині злочинця (провокуюча жертва); жертви, повністю винні у вчиненні щодо них злочину.

Класифікація за сутністю і характером соціальних контактів, які існували до вчи-

\footnotetext{
${ }^{1}$ Савчин М. В., Василенко Л.П. Вікова психологія : навч. посіб. Київ : Академ-видав-во, 2006. 360 с.
} 
нення злочину між злочинцем і потерпілим: особи, які перебувають зі злочинцем у різних відносинах спорідненості; діти та родичі знайомих; потерпілі, незнайомі зі злочинцем, які зустрілися з ним перед вчиненням злочину або зустрілися випадково, незадовго до нього.

Зазначена класифікація має прикладне значення, адже від характеру взаємозв'язків між потерпілою дитиною і злочинцем більшою мірою залежатиме спосіб учинення злочину та його продовжуваність.

На підставі проведеного нами дослідження вбачається, що наявність відносин спорідненості між дитиною і злочинцем сприяє збільшенню показника латентності вчинення злочинів проти статевої свободи та статевої недоторканості, пов'язаної із наявністю фізичного контакту, та їхньої тривалості, яка може у деяких випадках продовжуватися протягом кількох років. Водночас щодо незнайомих дітей показником тривалості $\epsilon$ вчинення статевих злочинів, не пов'язаних із фізичним контактом, які полягають у розбещенні неповнолітніх і домаганні дитини для сексуальних цілей.

Класифікація за характером поведінки: потерпілі із провокуючою поведінкою, потерпілі із непровокуючою поведінкою, потерпілі із нейтральною поведінкою.

Криміналістична класифікація способу злочину

Насамперед спосіб учинення злочину класифікується за стадією або за структурою способу вчинення злочину: спосіб підготовки, спосіб учинення, спосіб приховування.

Наявність або відсутність структурних компонентів способу вчинення злочину проти статевої свободи та статевої недоторканості дітей містить важливу криміналістично значущу інформацію, оскільки може надавати інформацію для обґрунтованого припущення щодо особи злочинця. Наприклад, якщо особа заздалегідь продумує способи приховування злочину, переодягається для його вчинення з метою унеможливлення потім упізнання ії за одягом; цілеспрямовано їде до навчального закладу, де навчаються діти; створює умови для вчинення злочину у вигляді усамітнення із потерпілою у туалеті, де і вчиняє злочин, то такі дії свідчать про їхню невипадкову спрямованість і наявність умислу.

Класифікація злочинів за наявністю спротиву вчинюваним діям: ті, що вчиняються без спротиву: вчинення дій сексуального характеру з особою, яка не досягла шістнадцятирічного віку, розбещення неповнолітніх і домагання дитини для сексуальних цілей; ті, яким дитина чинить опір (зґвалтування, сексуальне насильство, примушування до вступу у статевий зв'язок).

Класифікація за способом подолання опору дитини: за допомогою фізичного насильства; за допомогою психічного насильства; із використанням безпорадного стану потерпілої особи; із використанням введення в оману шляхом зловживання довірою.

Класифікація злочинів за характером дій, спрямованих на досягнення злочинного результату: ті, що вчиняються за обов'язкової наявності фізичного контакту між злочинцем і потерпілою особою; ті, для досягнення злочинного результату яких наявність фізичного контакту $\epsilon$ необов'язковою.

Зазначена класифікація способу вчинення злочину проти статевої свободи та статевої недоторканості $€$ важливою, оскільки від наявності чи відсутності фізичного контакту залежатиме слідова картина вчиненого злочину та, відповідно, негативні наслідки і спричинена шкода.

Криміналістична класифікація слідової картини

Класифікація слідової картини створює передумови для правильного орієнтування у складних ситуаціях під час розслідування злочинів проти статевої свободи та статевої недоторканості дітей, для свідомого підходу до вибору напрямку розслідування, розроблення версій.

За слідосприймаючим об'єктом сліди вчинення злочину проти статевої свободи та статевої недоторканості можна поділити на ідеальні сліди, матеріальні сліди, електронні (цифрові) сліди.

У свою чергу, матеріальні сліди вчинення злочину поділяються на сліди-відображення, сліди-речовини та запахові сліди, а сліди-відображення людини - на сліди рук, сліди ніг, сліди губ, зубів, нігтів. 
За наявністю геномної інформації людини сліди поділяються на сліди біологічного походження людини, що містять геномну інформацію, та сліди біологічного походження людини, що не містять геномну інформацію.

За процесуальним статусом особи, яка зберегла у своїй пам'яті ідеальні сліди: потерпілий, свідок, підозрюваний, обвинувачений.

Криміналістична класифікація обстановки вчинення злочину

За локалізацією злочинних дій: злочини, вчинені в одному місці; злочини, вчинені у різних місцях.
За ознаками місць безпосереднього вчинення злочинів: вчинені у приміщенні; вчинені на вулиці.

За часом доби: діяння, вчинені у денний час; діяння, вчинені у вечірній або нічний час.

Висновки. Криміналістична класифікація злочинів проти статевої свободи та статевої недоторканості сприяє розробленню криміналістичної характеристики і розумінню розвитку слідчих ситуацій; побудові загальних та окремих слідчих версій і розробленню методики розслідування такого виду злочинів; правильному вибору напрямку, методів і засобів розслідування кримінальних проваджень.

\section{ЛITEPATУРA:}

1. Корнієнко М. В. Концептуальні основи протидії насильницьким злочинам щодо дітей : монографія. Одеса : Одес. держ. ун-т внутр. справ, 2019. 318 с.

2. Авраменко С. М. Розслідування розбещення неповнолітніх : дис. ... канд. юрид. наук : 12.00.09. Київ, 2017. 242 с.

3. Гірук О. В. Тактика допиту малолітніх потерпілих від насильницьких злочинів : дис. ... канд. юрид. наук : 12.00.09. Київ, 2021. 250 с.

4. Тіщенко В. В. Концептуальні основи розслідування корисливо-насильницьких злочинів : автореф. дис. ... д-ра юрид. наук : 12.00.09. Харків, 2003. 34 с.

5. Синчук В. Л. Кореляційні залежності між елементами криміналістичної характеристики та їх використання у методиці розслідування вбивств : автореф. дис. ... канд. юрид. наук : 12.00.09. Харків, 2004. 20 с.

6. Пазинич Т. А. Криміналістична характеристика шахрайств та основні положення їх розслідування : автореф. дис. ... канд. юрид. наук : 12.00.09. Харків, 2007. 20 с.

7. Попович I. I. Криміналістичне забезпечення обігу розрахункових документів у банківській системі з метою запобігання вчиненню злочинів : автореф. дис. ... канд. юрид. наук : 12.00.09. Київ, 2007. 20 с.

8. Довбаш Р. С. Методика розслідування злочинів, пов'язаних з незаконним відшкодуванням податку на додану вартість : автореф. дис. ... канд. юрид. наук : 12.00.09. Київ, 2009. 20 c.

9. Лисенко В.В. Проблеми криміналістичного забезпечення розслідування податкових злочинів : дис... д-ра юрид. наук: 12.00.09. Київський національний ун-т внутрішніх справ. Київ, 2006. 20 с.

10. Матусовский Г. А. Экономические преступления: криминалистический анализ. Харьков : Консум, 1999. 480 с.

11. Щур Б. В. Криміналістична класифікація злочинів та ії роль в диференціації криміналістичних методик. Європейські перспективи. 2011. № 1. Ч. 2. С. 140-144.

12. Бахин В. П. Криминалистическая методика : лекция. Киев, 1999. 35 с.

13. Савчин М. В., Василенко Л. П. Вікова психологія : навч. посіб. Київ : Академвидав, 2006. 360 c. 